Alma Mater Studiorum - Università di Bologna DEPARTMENT OF ECONOMICS

\title{
Better Wed Over the Mixen Than Over The Moor? Break-ups of Inter-Ethnic Marriages In Italy
}

Laura Bottazzi

Paolo Manasse

Sarah Grace See

Quaderni - Working Paper DSE N¹098

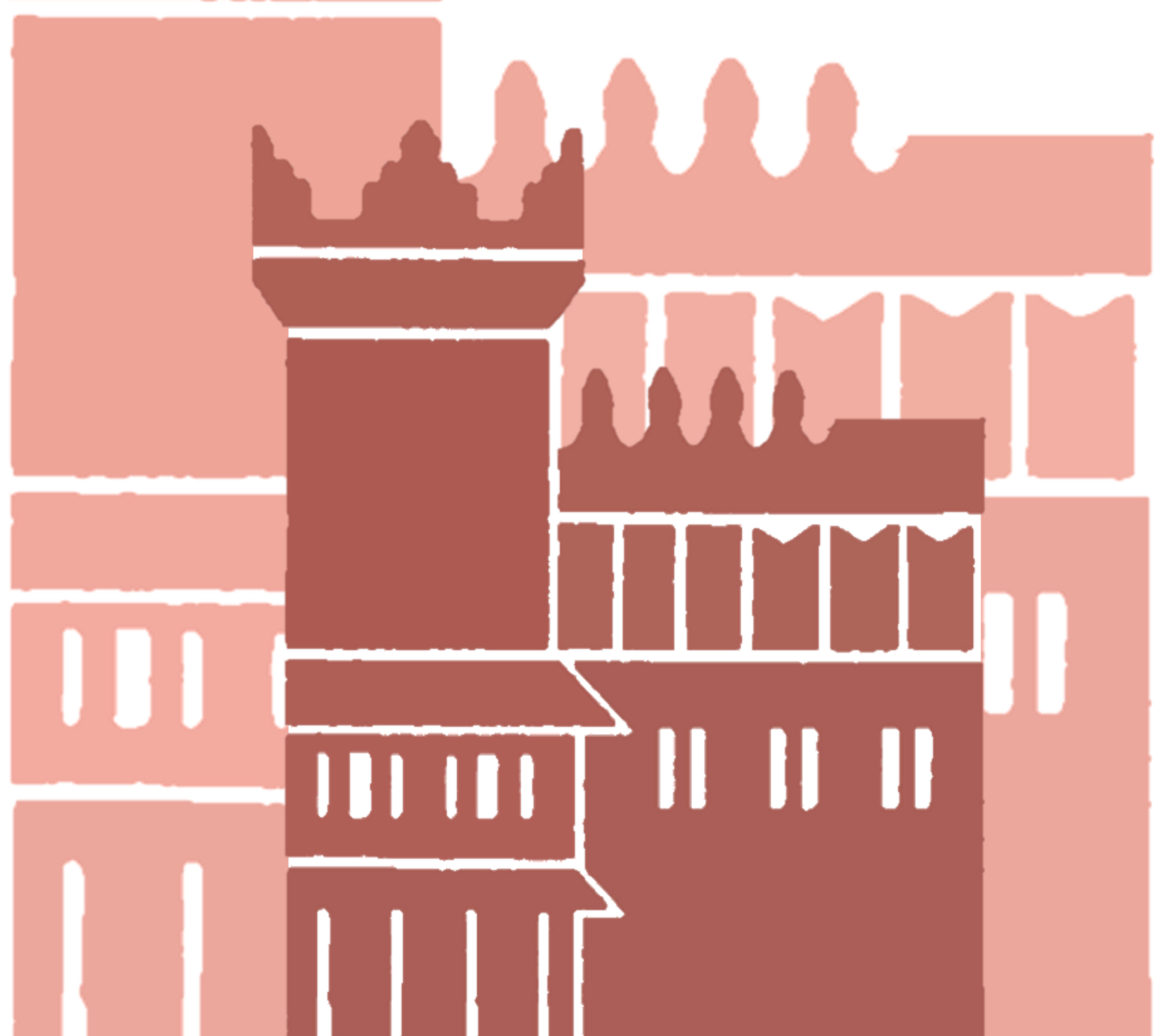




\title{
Better Wed Over the Mixen Than Over The Moor? Break-ups of Inter-Ethnic Marriages In Italy
}

\author{
By
}

\author{
Laura Bottazzi ${ }^{1}$ Paolo Manasse ${ }^{2}$ Sarah Grace $\mathrm{See}^{3}$
}

This Version: February 2017

\begin{abstract}
This paper studies the resilience of inter-ethnic marriages in Italy through the lenses of marriage duration by means of survival and treatment-effect analyses. Our main findings are that inter-ethnic marriages have a significantly higher risk of separation even when we control for social and economic characteristics of the spouses; however, when we restrict the analysis to more recent marriages, we observe that co- and inter-ethnic marriages converge in longevity. Finally, we find evidence of self-selection into inter-ethnic marriages. Overall our findings points to a society that is becoming increasingly open to cultural and ethnic diversity, as well as more secular.
\end{abstract}

Keywords: inter-ethnic marriage, divorce, separation, family economics

JEL Classification: J12

\footnotetext{
${ }^{1}$ Economics Department, University of Bologna, and IGIER Bocconi

${ }^{2}$ Economics Department, University of Bologna

${ }^{3}$ University of York, Collegio Carlo Alberto
} 


\section{Introduction}

Italy is historically a country of emigration with no relevant colonial past. Only recently it experienced a surge in immigration. The share of foreign (legal) residents in the population rose from 2.2 percent in 2002 to 8.1 percent in 2014. With the influx of immigrants came a considerable increase in inter-ethnic marriages, defined as those involving one native-born (i.e., Italian) and one foreign-born spouse. Against a declining trend of the number of marriages, reflecting a long-run shift towards new models of family and towards a more secular society, the share of inter-ethnic marriages rose sharply, from 4.4 to 14.8 percent between 1995 and 2012 (ISTAT, 2014).

A marriage of a non-native to a local is regarded as the ultimate form of assimilation of the former (Ham and Tammaru, 2011; Tolsma et al., 2008,). It exemplifies mutual social acceptance and openness of a society. The question asked in this paper is whether these marriages are less "stable" as compared to co-ethnic ones. We ask whether, from an empirical point of view, interethnic marriages are more prone to disruption than co-ethnic ones, as a result of cultural differences such as the role of women in society, religious beliefs, or the transmissions of values to children. These differences, on top of those relating to income, education, age, just to mention a few, are the focus of this paper. The issue of the resilience of inter-ethnic marriages is important for several reasons. First, it provides evidence on how cultural conflicts may affect the transmissions of values (Bisin and Verdier, 2010). Second, it documents the extent that integration has been, and is likely to be, successful in Italy, with important social and political implications in the context of the recent social alarm caused by the rapid surge in immigration.

This study exploits a novel micro data set, made available through a research agreement with the Italian Statistical Agency, ISTAT. The dataset covers the universe of all marriages and separations (the first step before divorce in the Italian law) that have taken place in Italy between 2008 and 2010. We estimate a number of empirical models in order to explain the determinants of the longevity of inter- and intra-ethnic marriages, our measure of "stability/resilience" of a marriage.

The outline of the paper is the following. Section 2 discusses the literature and notes that there are very few studies that satisfactorily address the issue of resilience of inter-ethnic marriages. Section 3 presents the data set on marriages and separations and shows that duration of inter-ethnic marriages is sensibly lower than that of co-ethnic couples. Section 4 employs econometric analyses to examine how robust this result is when we add controls for the different characteristics of the spouses. First, we estimate a "survival model" that accounts for important characteristics of the spouses, such as age, income, education, and employment status. We devote particular attention to computing measures of "distance," taking into account geography, proxies 
for religious beliefs, and for the ex-ante "attachment" to the marriage. Secondly, we employ treatment-effect analysis in order to address two important issues relating to the causal interpretation of our results. The first is that of the "missing counterfactual": what if spouses in inter-ethnic marriages had married a co-native? The second is self-selection into inter-ethnic marriage: what if the spouses who married foreign partners were among the least or the most attached to the idea of a (ever-) lasting marriage? To the best of our knowledge, the literature on the economics of marriages and divorces has never addressed these problems.

Our main findings, summarized in Section 5, are as follows. The (unconditional) average duration of an inter-ethnic marriage is about two-thirds of that of a marriage between co-natives. Even when we control for social and economic characteristics of the spouses, we find that interethnic marriages have a significantly higher risk of separation. In particular, separations occur earlier with the following conditions: when spouses marry younger, when either (but not both!) spouse is unemployed, when there are no kids, when the first kid is female, when spouses celebrate a civil (as opposed to religious) rite and choose a separation (as opposed to common) property regime, when the wife is more- and the husband less- educated, when spouses earn a higher income. However, when we restrict the analysis to more recent marriages, we observe that co- and interethnic marriages converge in longevity. Finally, we find evidence of self-selection into inter-ethnic marriages: spouses who are "less marketable" in the co-ethnic marriage market tend to self-select into inter-ethnic marriages. Spouses also self-select into inter-ethnic couples more frequently when they share the same religion. In the most recent cohorts of marriages, however, we observe a different kind of self-selection: spouses who are less attached to the (idea of ever-lasting) marriage are more likely to marry inter-ethnically. All these findings point to a society which is becoming increasingly open to cultural and ethnic diversity, and increasingly secular.

\section{A Review of the Literature.}

In his seminal contribution, Becker (1974) (see also Becker et al., 1977; Stevenson and Wolfers, 2007) discusses the reasons why people choose partners who are more (positive assortative mating) or less (negative assortative mating) similar to them in terms of shared values, tastes, abilities, and so on. This choice depends on the complementarity or substitutability of traits in the household's "production function." Characteristics such as shared values are complements, and as a consequence partners will prefer similar partners. For example, sharing the same culture is valuable as it makes education and values' transmission to children easier. In contrast, different abilities in market versus non-market activities can be considered as substitutes, so that "negative assortative mating" will occur. Having different abilities may be desirable, as it allows a task specialization 
within a couple ("raising the children" versus "bread-winning"), and this allows each partner to specialize in his/her comparative advantage, thus raising the family's income and welfare. Separations follow a similar logic, and depend on the comparison of the utility from the current match (marriage) relative to the expected utility of being single and possibly re-marrying in the future.

The theory suggests that spouses in inter-ethnic marriages that do not share important beliefs and values may separate earlier. Many studies find evidence of a higher risk of marital dissolution among inter-ethnic couples (Dribe and Lundh, 2011, Kalmijn et. al., 2005). Studies tend to attribute the instability of inter-ethnic marriages to cultural and religious "mismatches," which may generate conflict, reduce the value of the marriage, and lead to increased likelihood of a break-up. Heaton (2002) finds that a higher risk of dissolution is positively associated to the parents' experience of divorce, and is negatively associated to the presence and number of children, income, and job qualification. Children from inter-ethnic couples are also found to be exposed to a higher risk of marriage dissolution (Gruber, 2004).

There is a large empirical literature concerning the role of personal traits in positive versus negative assortative mating, (Dupuy and Galichon, 2014; Humbad et al., 2010). Studies have focused on physical and cultural traits, such as age (Choo, 2015; Choo and Siow, 2006); education (Jones, 2010); height, intelligence and religion (Kalmijn et al., 2005); race and ethnicity (Bratter and King, 2008, Feng et al., 2012; Frimmel et al., 2012); income and body mass index (Chiappori et al., 2012). Inter-ethnic marriages have been considered in the migration literature, in order to understand the process of assimilation (Algan et al., 2012; Constant and Zimmermann, 2008; Constant et al., 2009; Meng and Gregory, 2005).

While most empirical studies consider the issue of marriage stability in general, only a few ones focus on the relative risks of dissolution of inter- versus co-ethnic couples. Typically, these latter studies control for race, and rank the risk of dissolution of different types of couples, typically in the US and the UK. They find that the ethnic couples who are most at risk of dissolution are the Blacks, followed by the Whites and the Asians. Depending on data availability, cultural differences are typically measured by citizenship, race, ethnicity, place of birth (Monahan, 1970, Teachman, 2002 for the US; van Huis and Steenhof, 2003 for the Netherlands). Employing birthplace, race, and ethnicity, instead of citizenship, has the advantage that the former characteristics are individual time-invariant, so that we will use the place of birth in order to identify "inter-ethnic marriages." One of the few studies that explicitly consider marriage stability for inter-ethnic couples in Germany is Milewski and Kulu (2014). Their main finding is that inter-ethnic couples show higher dissolution rates compared to homogeneous (i.e., native-native and foreign-foreign) marriages, an 
effect which persists even when individual spouses' characteristics are taken into account. A major criticism of the empirical literature is that it is mainly descriptive and often fails to account for important "confounding factors" related to race/ethnicity. The typical example is age: inter-ethnic couples often tend to be younger, and younger couples may be more likely to separate (Feng et. al., 2012; Lehrer, 2008).

The literature on Italy is very scarce, particularly regarding the dissolution of inter-ethnic marriages. This is due to two main reasons: on the one hand, Italy legalized divorce only in 1970, relatively late compared to other countries ${ }^{1}$; on the other hand, immigration is a relatively recent phenomenon, so that, until a decade ago, inter-ethnic couples were very rare. De Rose (1992) is the first paper to study marital instability in Italy. He finds that women who enter into the marriage market earlier, who have better education and have full-time jobs, and who reside in large towns in the North West of Italy are the most exposed to the risk of marital disruption. Vignoli and Ferro (2009) analyse trends in legal separations between 1969 and 2003, and find that the probability of dissolution tends to increase until the fifth year of the marriage, peaks between the 3rd and the 8th year, and stabilizes afterwards. However, they do not consider inter-ethnic marriages. Manasse and See (2013) use ISTAT Census data for marriages to analyse marriage dissolution of inter-ethnic couples. They find evidence of a gender gap: Italian women in inter-ethnic marriages are more likely to separate than their co-ethnic counterparts, while Italian men are less likely to do so. However, their data track the life of a marriage for a few years from the celebration date, so their analysis cannot cover most of the separations that occur later in the marriage life.

This paper considers the issue of the resilience of inter-ethnic couples from another perspective: marriage duration. We look at marriages that end-up in separations, so that our observations can track back in time the entire history and duration of each marriage. Moreover, we improve on the current literature in many ways. We consider many confounding factors, in particular several measures of "distance” among spouses (geographical, economic, and cultural). From a methodological point of view, we improve upon the literature by addressing the issue of causality with treatment-effects techniques. In fact, we address two important problems that have been completely neglected by the literature. The first is the long-standing issue of the missing counterfactual: in order to assess the causal effect of an inter-ethnic marriage on the marriage duration, we should know how the marriage would have lasted had either spouse married a conative instead of a foreigner (and vice-versa for a co-ethnic marriage), an event which of course we

\footnotetext{
${ }^{1}$ The initial legislation of divorce, which was passed after a Referendum, was quite strict, requiring 5 years of prior legal separation and a court verdict. This was amended in 1987, with the requirement being reduced to three years, and recently in 2015 to one year (six months for consensual separations). Note that only 6 in 10 separations end in a divorce, given that there are considerable legal costs involved. Thus many studies, including ours, focus on legal separations (Salvini and Vignoli, 2011) for a discussion of Italian legislation.
} 
do not observe. The second problem is that of endogeneity, namely the fact that the assignment of our "treatment" (marrying a foreign partner) is non-random, and may be correlated to the outcome (the time to separation). In short, the choice of marrying a foreign spouse may depend on some of the spouse's characteristics which we do not (fully) observe, and that may influence the choice of marrying a foreigner and the dissolution of the marriage simultaneously.

\section{The Data}

Thanks to a research agreement with ISTAT, the Italian Statistical Agency, we have access to the Census of separations (258.302 separations) and the Census of marriages (694,004 marriages) for the years 2008-2010, which record all the separations and marriages that occurred in Italy during this period. The datasets contain information on dates (wedding, separation, and divorce); the type of wedding rite (civil/religious); the regime of property chosen by the couple (commonality/separation); the type of separation agreement (judicial/consensual); the value of "money transfers" between ex-spouses and the house assignment; and the terms of children custody. It also contains information on the individual spouses, such as their places of residence, birth dates, marital status prior to marriage, the number, sex, and ages of children at separation, the assignments of children after the separation, the spouses' educational attainment, place of birth, and citizenship (but there is no individual information on race, ethnicity, religion). Concerning the spouses' economic status, we observe their employment/unemployment situation, and if employed, the type and sector of occupation. As explained earlier, and unlike Manasse and See, 2013, this paper does not employ the Census marriage data for the empirical analysis, because we cannot track what happens to marriages beyond 2010. Instead, the Census for separations contains records of marriages that lasted from 0 to 65 years, and which ended in a separation during the period of observation, 2008-10 and this enables us to evaluate the duration of marriages. ${ }^{2}$ In the analysis, we consider the "time-to-separation" or the longevity as our measure of "marriage resilience."

Table 1 contains a number of descriptive statistics of the characteristics of the sample analysed. The table classifies marriages and separations in five types: co-ethnic with both Italianborn spouses, inter-ethnic with Italian husband, inter-ethnic with Italian wife, co-ethnic with both foreign spouses born in the same country, and inter-ethnic with both foreign spouses but born in different countries. We observe the full population of separations that occurred in Italy in the years 2008, 2009, and 2010 (see Panel A). Each wave contains comparable though increasing number of observations of couples separating each year. In every year, (separations of) co-ethnic marriages

\footnotetext{
${ }^{2}$ The Census divorce dataset contains only information on those marriages that end up in a divorce, which according to the Italian law of this period require at least three years of prior legal separation. This dataset therefore contains less information compared to the Census of separations, so we do not use it in the analysis.
} 
between Italian spouses represent the bulk of the observations (3-year average of 88.8 percent, see first row of the table). Looking at the "year of marriage," we can see the strong increase in the frequency of inter-ethnic marriages in the sample: for example, inter-ethnic marriages with Italian husbands constitute about 6.6 percent of all marriages that end in a separation in 2008 and rise to 8.10 percent in 2010. This is apparent also by looking at different cohorts of marriages: among the total number of the inter-ethnic marriages with Italian husbands (wife) recorded in our sample, those celebrated in the period 1942-1980 make up only 4.30 percent (4.9 percent, respectively), compared to 3 percent (49 percent, respectively) that were celebrated in the most recent period of 2001-2010.

\section{Year and Duration of Marriages}

Panel A of the table also shows the distribution of marriages by decade in the sample. In total, marriages celebrated between 1942 and 1980 are about 13 percent of the observations, while those celebrated in the period 1981-1994 are about 35 percent; marriages celebrated in 1995-2000 and in 2001-2010 are about 22 percent and 30 percent of the sample, respectively.

The table shows the average resilience or longevity of marriages in the sample, our variable of interest, also visualized in Figure 1.

In the entire sample, co-ethnic marriages between Italian-born couples last about 15.6 years on average, while inter-ethnic couples are less durable. Those with Italian husbands last considerably less, about 9.9 years, and those with Italian wives about 10.5 years. The least durable are the inter-ethnic couples of different countries of origin, lasting an average of 8.4 years. 


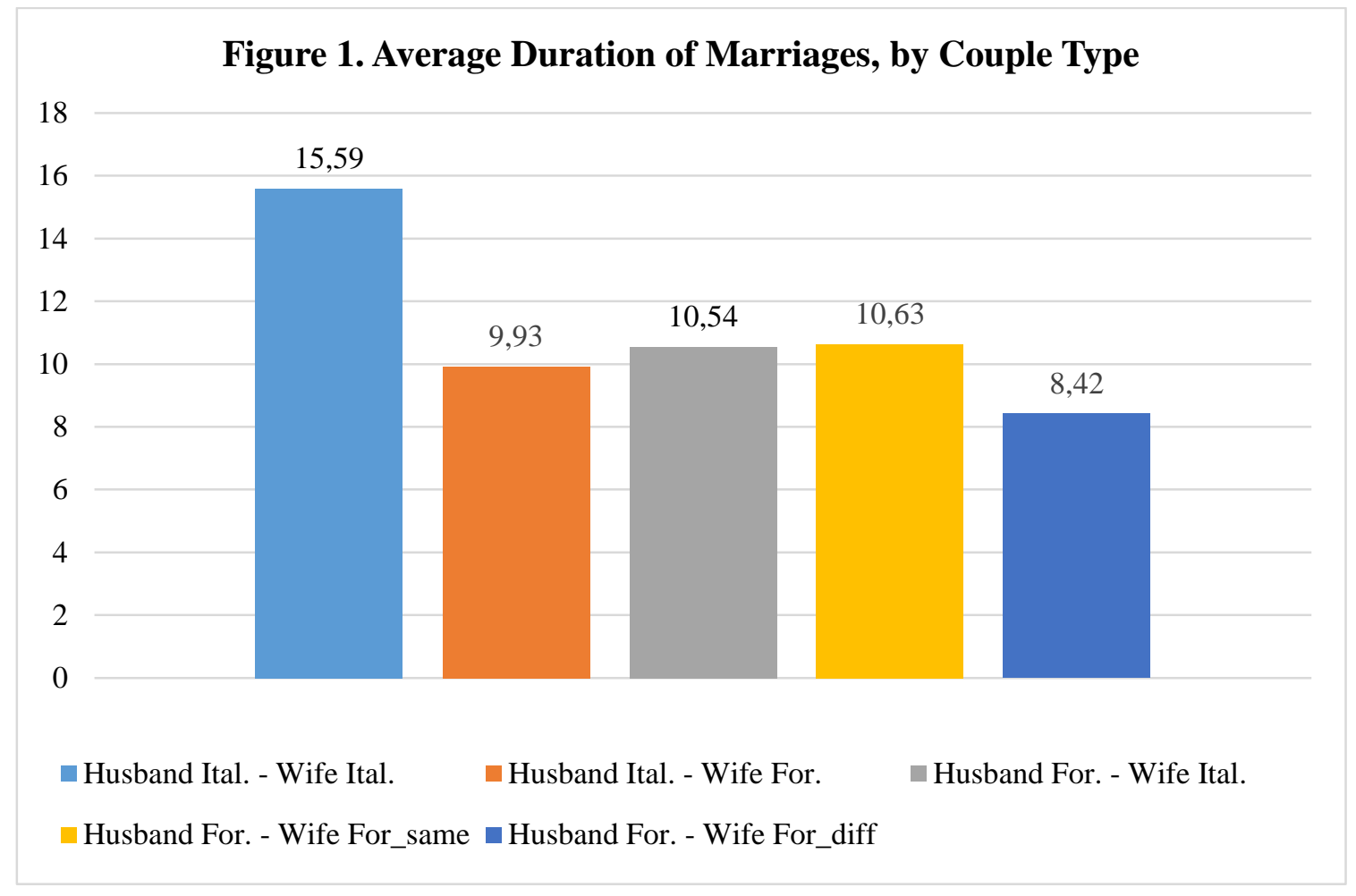

\section{Origin of Spouses}

Table 1 also provides information about the origins of foreign partners in inter-ethnic marriages. Most foreign partners of Italian spouses were borne in other European countries: 69.7 percent of foreign husbands and 77.1 percent of foreign wives. In particular, Italian men and women tend to marry spouses born in neighbouring countries (not shown in the table), such as Austria (12 percent of inter-ethnic marriages for both Italian husband and wives) and Switzerland (3 percent and 5.2 percent, respectively), or born in traditional emigration destinations, such as Germany (2.7 percent and 4.4 percent) and Belgium (2.3 percent and 3.4 percent). The most frequent cases however are that of Albanians (21 percent and 19 percent of foreign wives and husbands, respectively) followed by Romanians (4 percent of foreign wives but only 1.2 percent of foreign husbands). Italian men and women differ in their second-most popular foreign partners. Latin American and Caribbean wives come second for Italian men (10.5 percent of their inter-ethnic marriages) but only third for Italian women (6.2 percent). Brazilians and Cubans are the most popular from this region (2.6 percent and 2.4 percent of foreign wives, and 1.2 percent and 1 percent of foreign husbands, respectively). By contrast, Middle Eastern-North-African and SubSaharan African partners are the second most frequent foreign husbands of Italian women (14 percent and 3.6 percent, respectively), with Morocco (4.2 percent), Egypt (4.1percent), Tunisia (2.5 percent) and Senegal (1 percent) as the most frequent origin. These countries are virtually absent 
among the foreign wives of Italian men. The opposite is true for Eastern Europe: spouses from Ukraine, Poland, and Moldavia are relatively frequent among inter-ethnic couples with Italian husbands (1.4 percent, 1.2 percent, and 1 percent, respectively), but absent in those with Italian wives.

The geographical composition of inter-ethnic marriages is likely to depend on preferences for cultural proximity, a topic that we will discuss below, but surely also reflect the "supply side" factors linked to the composition of immigration. Available data from ISTAT (2014) reveal that while the total number of male immigrants is similar to the total number of female immigrants, there are strong genre asymmetries in their geographical origins. Females exceed males among immigrants from Eastern European countries, with very high female/male ratio for Ukraine (3.75 percent), Poland (2.8 percent). Moldova (1.9 percent), Bulgaria (1.7 percent). The opposite is true for African countries such as Senegal (0.4 percent), Egypt (0.5 percent), Tunisia (0.6 percent), and Ghana (0.72 percent), where immigrants are predominantly male. As a consequence, Eastern European women and African men are in "excess supply" in the "co-ethnic" marriage market, which may account for the relatively high frequency of inter-ethnic marriages involving eastern European wives and African husbands.

\section{Geography}

We also consider the role of geographic distance between the spouses' cities of birth exploiting the Geo database. We are interested to see if, for example, marriages of spouses born in far-apart Italian towns (e.g., in Friuli in the North East and in Sicily) are more "fragile" than those born in the same place. For inter-ethnic couples, we calculate the distance between Rome and the foreign capital. The descriptive statistics in Panel A of Table 1 show that the sample average distance of Italian spouses' place of birth of 147 kilometres is not negligible.

\section{Socio-economic Characteristics}

Panel A also shows the descriptive statistics for the spouses' characteristics. The average age difference between husband and wife is about 3.3 years. Inter-ethnic couples are however noticeably different from the other types: Italian husbands in inter-ethnic marriages are considerably older at marriage than the Italian men in co-ethnic couples (35 against 29 years), and the age difference between spouses is more than twice the average in magnitude (7.1 against 3.1 years). Conversely, Italian wives in inter-ethnic marriage have almost the same age as their foreign husbands. 
Concerning education, "positive assortative mating" seems to prevail in the sample, with about 63 percent of spouses having similar education levels and about one-fourth of the couples having more educated husbands (not shown in the table). Interestingly, Italian husband in interethnic couples are significantly less educated than Italian husbands in co-ethnic marriages, with a higher percentage of the sample reaching secondary education (45 percent against 40 percent), and a lower percentage with high school education (38 percent against 40 percent). A similar, but less pronounced, pattern holds true for Italian wives in inter-ethnic marriages, with higher percentage of the sample with secondary education, and those with high school diploma slightly lower than in coethnic marriage (39 vs 35 percent and 43 vs 44 percent, respectively).

The presence of children, which is possibly the most important outcome of a marriage, is starkly different between co-ethnic and inter-ethnic couples recorded in the Census. About 55 percent (45 percent) of inter-ethnic couples with Italian husbands (wives, respectively) have no children, compared to only 29 percent (33 percent) of Italian (respectively, foreign same-country) co-ethnic marriages.

Moving to economic characteristics that are reported in Panel B, the table reveals some interesting information. Spouses in co-ethnic marriages (both Italian and foreign) are the most likely to have both spouses employed, compared to those in inter-ethnic ones. Meanwhile, both the foreign wives and foreign husbands in inter-ethnic marriages are more likely to be unemployed compared to their Italian counterparts in co-ethnic marriages. 
Table 1. Census of Separations (Panel A)

\begin{tabular}{|c|c|c|c|c|c|c|}
\hline PANEL A & Full sample & $\begin{array}{l}\text { Husband Ital. - Wife } \\
\text { Ital. }\end{array}$ & $\begin{array}{l}\text { Husband Ital. - Wife } \\
\text { For. }\end{array}$ & $\begin{array}{l}\text { Husband For. - Wife } \\
\text { Ital. }\end{array}$ & $\begin{array}{l}\text { Husband For. - Wife } \\
\text { For_same }\end{array}$ & $\begin{array}{l}\text { Husband For. - Wife } \\
\text { For_diff }\end{array}$ \\
\hline Observations (\%) & $258,302(100.00)$ & $229,459(88.81)$ & $17,235(6.67)$ & $8,402(3.25)$ & $2,253(0.87)$ & $953(0.37)$ \\
\hline \multicolumn{7}{|l|}{ Year of Separation/Waves, $n(\%)$} \\
\hline 2008 & $84,165(32.58)$ & $74,981(89.09)$ & $5,544(6.59)$ & $2,633(3.13)$ & $751(0.89)$ & $256(0.30)$ \\
\hline 2009 & 85,945 (33.27) & $78,395(91.22)$ & $4,546(5.29)$ & $2,146(2.50)$ & $643(0.75)$ & $215(0.25)$ \\
\hline 2010 & $88,192(34.14)$ & $76,083(86.27)$ & $7,145(8.10)$ & $3,623(4.11)$ & $859(0.97)$ & $482(0.55)$ \\
\hline \multicolumn{7}{|l|}{ Year of Marriages, $n(\%)$} \\
\hline $1942-1980$ & $33,148(12.83)$ & $31,883(13.89)$ & $741(4.30)$ & $414(4.93)$ & $81(3.60)$ & $29(3.04)$ \\
\hline 1981-1994 & $90,252(34.94)$ & $83,947(36.58)$ & $3,514(20.39)$ & $2,028(24.14)$ & $606(26.90)$ & $157(16.47)$ \\
\hline $1995-2000$ & $57,759(22.36)$ & $51,303(22.36)$ & $3,903(22.65)$ & $1,828(21.76)$ & $539(23.92)$ & $186(19.52)$ \\
\hline $2001-2010$ & $77,143(29.87)$ & $62,326(27.16)$ & $9,077(52.67)$ & $4,132(49.18)$ & $1,027(45.58)$ & $581(60.97)$ \\
\hline Duration of Marriage, in years & $14.98(10.55)$ & $15.59(10.64)$ & $9.93(8.13)$ & $10.54(8.70)$ & $10.63(8.37)$ & $8.42(7.62)$ \\
\hline \multicolumn{7}{|l|}{ Regions } \\
\hline Husband, Asia Pacific & $258(0.10)$ & & & $148(2.38)$ & $88(6.33)$ & $22(3.02)$ \\
\hline Husband, Europe & $252,293(98.93)$ & $229,459(100.00)$ & $17,235(100.00)$ & $4,327(69.67)$ & $808(58.13)$ & $464(63.65)$ \\
\hline Husband, Latin America-Caribbean & $886(0.35)$ & & & $524(8.44)$ & $281(20.22)$ & $81(11.11)$ \\
\hline Husband, Middle East-North Africa & $1,068(0.42)$ & & & $856(13.78)$ & $111(7.99)$ & $101(13.85)$ \\
\hline Husband, North America & $149(0.06)$ & & & $132(2.13)$ & $3(0.22)$ & $14(1.92)$ \\
\hline Husband, Sub-Saharan Africa & $370(0.15)$ & & & $224(3.61)$ & $99(7.12)$ & $47(6.45)$ \\
\hline Wife, Asia Pacific & $479(0.19)$ & & $358(2.66)$ & & $88(6.33)$ & $33(4.26)$ \\
\hline Wife, Europe & $249,582(98.46)$ & $229,459(100.00)$ & $10,379(77.13)$ & $8,402(100.00)$ & $808(58.13)$ & $534(68.90)$ \\
\hline Wife, Latin America-Caribbean & $2,213(0.87)$ & & & & $281(20.22)$ & $129(16.65)$ \\
\hline Wife, Middle East-North Africa & $554(0.22)$ & & & & $111(7.99)$ & $34(4.39)$ \\
\hline Wife, North America & $244(0.10)$ & & & & $3(0.22)$ & $5(0.65)$ \\
\hline Wife, Sub-Saharan Africa & $410(0.16)$ & & & & $99(7.12)$ & $40(5.16)$ \\
\hline Geographical distance of birthplaces, in kilom & $587.82(1728.55)$ & $147.71(330.29)$ & $5,779.95(2936.76)$ & $5,375.84(2619.67)$ & $0.00(0.00)$ & $3,642.55(3793.00)$ \\
\hline \multicolumn{7}{|l|}{ Ages and age differences, in years (sd) } \\
\hline Age difference & $3.26(5.35)$ & $3.07(4.69)$ & $7.13(8.81)$ & $0.33(7.76)$ & $3.23(6.16)$ & $3.64(8.39)$ \\
\hline Husband's age & $29.61(6.86)$ & $29.22(6.37)$ & $34.85(10.28)$ & $29.25(6.24)$ & $29.51(6.78)$ & $32.13(8.06)$ \\
\hline Wife's age & $26.35(6.10)$ & $26.15(5.89)$ & $27.72(7.01)$ & $28.92(8.10)$ & $26.28(6.62)$ & $28.48(7.03)$ \\
\hline \multicolumn{7}{|l|}{ Education categories, $n(\%)$} \\
\hline Husband, graduate education & $28,301(10.96)$ & $25,462(11.10)$ & $1,585(9.20)$ & $974(11.59)$ & $188(8.34)$ & $92(9.65)$ \\
\hline Husband, college diploma & $4,469(1.73)$ & $3,915(1.71)$ & $284(1.65)$ & $196(2.33)$ & $51(2.26)$ & $23(2.41)$ \\
\hline Husband, high school diploma & $103,289(39.99)$ & $92,211(40.19)$ & $6,473(37.56)$ & $3,311(39.41)$ & $903(40.08)$ & $391(41.03)$ \\
\hline Husband, secondary education & $104,511(40.46)$ & $92.099(40.14)$ & $7,704(44.70)$ & $3,374(40.16)$ & $944(41.90)$ & $390(40.92)$ \\
\hline Husband, elementary education & $17,732(6.86)$ & $15,772(6.87)$ & $1,189(6.90)$ & $547(6.51)$ & $167(7.41)$ & $57(5.98)$ \\
\hline Wife, graduate education & 31,205 (12.08) & $27,703(12.07)$ & $2,290(13.29)$ & 930 (11.07) & $184(8.17)$ & $98(10.28)$ \\
\hline Wife, college diploma & $7,103(2.75)$ & $6,117(2.67)$ & $619(3.59)$ & $249(2.96)$ & $75(3.33)$ & $43(4.51)$ \\
\hline Wife, high school diploma & $114,002(44.14)$ & $101,396(44.19)$ & 7,591 (44.04) & $3,624(43.13)$ & $958(42.52)$ & $433(45.44)$ \\
\hline Wife, secondary education & $90,269(34.95)$ & $79,854(34.80)$ & $5,968(34.63)$ & $3,253(38.72)$ & $866(38.44)$ & $328(34.42)$ \\
\hline Wife, elementary education & $15,723(6.09)$ & $14,389(6.27)$ & $767(4.45)$ & $346(4.12)$ & $170(7.55)$ & $51(5.35)$ \\
\hline \multicolumn{7}{|l|}{ Children, $n(\%)$} \\
\hline No kids & $81,090(31.39)$ & $66,533(29.00)$ & $9,452(54.84)$ & $3,780(44.99)$ & $741(32.89)$ & $522(54.77)$ \\
\hline First kid is female & $61,879(23.95)$ & $56,187(24.49)$ & $3,040(17.64)$ & $1,875(22.32)$ & $590(26.19)$ & $187(19.62)$ \\
\hline
\end{tabular}


Table 1. Census of Separations (Panel B)

\begin{tabular}{|c|c|c|c|c|c|c|}
\hline PANEL B & Full sample & $\begin{array}{l}\text { Husband Ital. - Wife } \\
\text { Ital. }\end{array}$ & $\begin{array}{l}\text { Husband Ital. - Wife } \\
\text { For. }\end{array}$ & $\begin{array}{l}\text { Husband For. - Wife } \\
\text { Ital. }\end{array}$ & $\begin{array}{l}\text { Husband For. - Wife } \\
\text { For_same }\end{array}$ & $\begin{array}{l}\text { Husband For. - Wife } \\
\text { For_diff }\end{array}$ \\
\hline \multicolumn{7}{|c|}{ - } \\
\hline Both are employed & $151,966(58.82)$ & $136,465(59.47)$ & $8,754(50.79)$ & $4,779(56.88)$ & $1,419(62.98)$ & $549(57.61)$ \\
\hline Husband is unemployed-Wife is employed & $16,844(6.52)$ & $14,008(6.10)$ & $1,694(9.83)$ & $852(10.14)$ & $201(8.92)$ & $89(9.34)$ \\
\hline Husband is employed-Wife is unemployed & $59,931(23.20)$ & $52,535(22.90)$ & $4,767(27.66)$ & $1,914(22.78)$ & $482(21.39)$ & $233(24.45)$ \\
\hline Both are unemployed & $29,561(11.44)$ & $26,451(11.53)$ & $2,020(11.72)$ & $857(10.20)$ & $151(6.70)$ & $82(8.60)$ \\
\hline \multicolumn{7}{|l|}{ Income, in euros ( $s d$ ) } \\
\hline Difference & $4,251.16(5927.39)$ & $4,250.42(5698.72)$ & $4,593.68(7695.30)$ & $3548.32(7158.04)$ & $4,342.84(6732.20)$ & $4,431.33(7252.19)$ \\
\hline Husband's income & $14,453.49(5686.38)$ & $14,433.11(5580.09)$ & $14,724.05(6716.24)$ & $14,196.52(6108.27)$ & $14,968.24(5596.16)$ & $15,305.22(6087.12)$ \\
\hline Wife's income & $10,376.17(5386.28)$ & $10,376.61(5347.71)$ & $10,125.22(5677.86)$ & $10,734.30(5785.81)$ & $10,593.83(5220.15)$ & $10,805.47(5524.26)$ \\
\hline \multicolumn{7}{|l|}{ Religion: Wedding rite, $n(\%)$} \\
\hline Civil & $82,509(31.94)$ & $63,135(27.51)$ & $11,917(69.14)$ & $4,953(58.95)$ & $1,742(77.32)$ & $762(79.96)$ \\
\hline Religious & $175,793(68.06)$ & $166,324(72.49)$ & $5,318(30.86)$ & $3,449(41.05)$ & $511(22.68)$ & $191(20.04)$ \\
\hline \multicolumn{7}{|l|}{ Property Regime, $n(\%)$} \\
\hline Separate ownership & $127,152(49.23)$ & $110,887(48.33)$ & $9,995(57.99)$ & $4,864(57.89)$ & 898 (39.86) & $508(53.31)$ \\
\hline Joint ownership & $131,150(50.77)$ & $118,572(51.67)$ & $7,240(42.01)$ & $3,538(42.11)$ & $1,355(60.14)$ & 445 (46.69) \\
\hline \multicolumn{7}{|l|}{ Marriage history, $n(\%)$} \\
\hline Husband First-Wife First & $246,667(95.50)$ & $220,877(96.26)$ & $15,072(87.45)$ & 7,784 (92.64) & $2,091(92.81)$ & $843(88.46)$ \\
\hline Husband First-Wife Second & $4,351(1.68)$ & $3,040(1.32)$ & $840(4.87)$ & $341(4.06)$ & $75(3.33)$ & $55(5.77)$ \\
\hline Husband Second-Wife First & $5,048(1.95)$ & $3,817(1.66)$ & $933(5.41)$ & $204(2.43)$ & $58(2.57)$ & $36(3.78)$ \\
\hline Husband asks for the separation & $21,142(8.18)$ & $17,833(7.77)$ & $2,499(14.50)$ & $529(6.30)$ & $177(7.86)$ & $104(10.91)$ \\
\hline
\end{tabular}


Census data do not provide information on incomes. As such, we imputed the spouses' incomes by matching our data with the Bank of Italy's Survey on Households' Income and Wealth of 2010. The match is done by defining "cells" on the basis of age, education, sex, and place of residence, and by attributing to each spouse in our dataset's cell the median income of the corresponding cell recorded in the Bank of Italy survey. The figures in Panel B of Table 1 show that all types of couples are quite similar in terms of (imputed) income and income differences between spouses.

\section{Commitment to Marriage}

We do not observe the religious beliefs of spouses. Nevertheless, we know their choice of a religious or a civil wedding rite. A religious wedding rite is automatically registered by the Italian law. The substantial difference between a religious and civil rite, apart from the choreography of the ceremony, is that the Catholic rite, which is by far the most common, does not contemplate the possibility of a divorce ${ }^{3}$ : "what God has joined together, let man not separate" (Mark, 10:9). Should spouses decide to separate, their decision would not be recorded by the Church, and spouses would be discriminated by the Catholic community and denied access to the Sacraments (like Eucharist or Last Rite). In our sample, the vast majority, 72.5 percent of Italian-only marriages, were celebrated according to a religious rite. This percentage falls dramatically for all other marriages, with interethnic marriages of different birth countries at the lowest (20 percent) followed by foreign co-ethnic marriages (23 percent), inter-ethnic with Italian husband (31 percent) and wife (41 percent). This is not surprising, given that, unlike Italian couples, inter-ethnic couples do not always share the same religion. Recall, however, that a vast majority of inter-ethnic marriages involves Europeans and Southern Americans who are prevalently Christians (although not necessarily Catholic). We will interpret the choice of the rite as a proxy for religiously motivated commitment to marriage.

The Italian law requires that, before marrying, the couple expresses a preference for a separate or a common property regime. In the former, the property (e.g., a house) acquired after the marriage is attributed pro-rata depending on the spouses' contributions; in the "common" regime the new property is considered "joint property" of the couple. Clearly, the latter choice implies a higher litigation costs in case of separation. We will interpret the choice of property regime as a proxy of (non-religiously motivated) ex-ante commitment to the marriage. Table 1 Panel B shows that more Italian inter-ethnic couples, about 58 percent, choose a "separation regime" compared to Italian-only couples (48 percent). Note however that this result in preference is reversed when we move to marriages celebrated in the most recent period (not shown in the table).

\footnotetext{
${ }^{3}$ The marriage can however be declared "void" by the "Sacra Rota" tribunal of the Vatican through a very costly process.
} 


\section{Marriage history and "balance-of-power"}

Finally, in terms of marriage history, inter-ethnic marriages feature a considerably larger share of spouses at their second (or higher) marriage, compared to Italian co-ethnic ones. About 12.5 percent (7.3 percent) of inter-ethnic marriages with Italian husbands (wives) have at least one of the spouses who has remarried, compared to only 3.7 percent in Italian co-ethnic marriages. The spouse at his second (or higher) wedding in inter-ethnic couples is more often the Italian one.

Finally, an interesting feature of our data concerns the information on whether it is the husband, wife, or both, who is applying for the separation, which we interpret as a measure of the spouses" "balance of power" within the couple. Separations are typically consensual or requested by the wife. Among Italian co-ethnic couples, only 7.8 percent of separations are unilaterally requested by the husband. Interestingly, this percentage rises significantly to 14.5 percent for Italian husbands in inter-ethnic couples, while it falls somewhat to 6.3 percent for foreign husbands in inter-ethnic marriages. This may suggest that Italian spouses in inter-ethnic couples are relatively more "powerful" than those in co-ethnic marriages.

\section{Econometric Analysis}

In this section we ask whether the difference in the average marriage longevity between inter- and co-ethnic couples discussed above persists when we control for the spouses' characteristics. We will adopt different methodological approaches in order to check for the robustness of the results. We start by estimating a survival model for the time to separation. This gives us a simple benchmark for the importance of inter-ethnic marriages.

\subsection{Hazard rates}

Next we estimate the hazard rate of a separation. Hazard rates are common in empirical and theoretical labour economics, although less so in the empirical literature on marriages. The hazard rate for a couple $m$ at time $t, h_{m}(t)$, is the probability that the couple will separate in the interval $t$, $t+d t$, conditional upon the marriage having survived until time $t$. Hazard rates are modelled as a function of each spouses' characteristics, and are estimated by using the Cox proportional hazard rate regression model (Cox, 1972). The first column of Table 2 shows the estimation results when the time to separation, $\_$, is assumed to depend only on the binary dummy variable "mixed", which takes the value of 1 if the spouses are born in different countries, and 0 otherwise. All the regressions in the table include year dummies and continent-of-birth dummies (Europe, AsiaPacific, Middle East-North Africa, Sub-Saharan Africa, Latin America-Caribbean, and North 
America). A coefficient's estimate for the inter-ethnic dummy above (below) the value of one means a higher (lower) hazard rate of inter-ethnic relative to co-ethnic couples, and thus a shorter marriage. Controlling for time effects and continent of birth, we obtain a (statistically significant) estimate of the coefficient of 1.65 (see the first column in Table 2). This implies that an inter-ethnic marriage has an instantaneous probability to break up that is 65 percent higher than a co-ethnic marriage. The consequence is that inter-ethnic marriages last on average 5.9 years less than the average. $^{4}$

The second column in the table introduces the finer definition of inter-ethnic marriages discussed in the previous section. This regression excludes the marriages between Italians, such that the estimated coefficients indicate the hazard rates relative to this couple. Given that all coefficients exceed unity, the Italian co-ethnic marriage is the most durable type, followed by marriages of coethnic foreign spouses. The least durable are marriages of inter-ethnic foreign couples, which display a hazard rate that is almost twice that of the Italian co-ethnic couple. Inter-ethnic marriages with Italian husbands are slightly more at risk of dissolution than inter-ethnic couples with Italian wives but the difference is not statistically significant. This finding is somewhat at odds with Manasse and See (2013), which find that the probability of marriage ending in a separation is higher for inter-ethnic couples with Italian wives relative to inter-ethnic couples with Italian husbands. ${ }^{5}$ Given that survival rates do not differ significantly according to genre, the next analyses will concentrate on the binary classification of mixed (different country of birth) vs non-mixed.

The third column in Table 2 introduces individual characteristics of the couples: age, previous marriages, children, education, employment status, and imputed income. The main result shown in column 3 of Table 2 is that introducing additional controls does not reduce the coefficient of the "mixed" dummy variable, which remains statistically different from zero and actually rises to 1.77 , implying a negative impact of an inter-ethnic marriage on duration of 6.5 years.

\footnotetext{
${ }^{4}$ Given that the average time to separation is 15 , a simple estimate of the difference between the duration of the average and the inter-ethnic marriages, is $d=15 *(1-(1 / h))$, where $h$ is the estimated relative hazard rate.

${ }^{5}$ The two findings are not necessarily in contradiction: the current sample of analysis looks at marriages that end up in separations, so that it is conceivable that a type of couple may have a lower probability of separation at marriage, but, conditional on separating, splits earlier.
} 
Table 2. Hazard Rates Estimates for Co- and Interethnic Couples (Cox Regressions)

\begin{tabular}{|c|c|c|c|c|c|}
\hline VARIABLES & $\begin{array}{c}\mathrm{t}: 1947-2010 \\
(1) \\
\end{array}$ & $\begin{array}{c}\mathrm{t}: 1947-2010 \\
(2) \\
\end{array}$ & $\begin{array}{c}\mathrm{t}: 1947-2010 \\
(3)\end{array}$ & $\begin{array}{c}\mathrm{t}: 1980-2010 \\
(4)\end{array}$ & $\begin{array}{c}\mathrm{t}: 1994-2010 \\
(5) \\
\end{array}$ \\
\hline Mixed & $\begin{array}{c}1.6551 * * * \\
(0.016)\end{array}$ & & $\begin{array}{c}1.7718 * * * \\
(0.035)\end{array}$ & $\begin{array}{c}1.7381 * * * \\
(0.036)\end{array}$ & $\begin{array}{c}1.1887 * * * \\
(0.030)\end{array}$ \\
\hline Husband Ital.- Wife For. & & $\begin{array}{c}1.7403 * * * \\
(0.020)\end{array}$ & & & \\
\hline Wife Ital.-Husband For & & $\begin{array}{c}1.5644 * * * \\
(0.026)\end{array}$ & & & \\
\hline Husband For.-Wife For_same & & $\begin{array}{c}1.4586 * * * \\
(0.051)\end{array}$ & & & \\
\hline Husband For.-Wife For_diff. & & $\begin{array}{c}1.9196^{* * * *} \\
(0.108)\end{array}$ & & & \\
\hline Husband Second-Wife Second & & & $\begin{array}{c}0.7206^{* * * *} \\
(0.018)\end{array}$ & $\begin{array}{c}0.6872 * * * \\
(0.018)\end{array}$ & $\begin{array}{c}0.7748 * * * \\
(0.022)\end{array}$ \\
\hline Husband First - Wife Second & & & $\begin{array}{c}0.9371 * * * \\
(0.019)\end{array}$ & $\begin{array}{c}0.8900 * * * \\
(0.020)\end{array}$ & $\begin{array}{c}0.9483 * * \\
(0.020)\end{array}$ \\
\hline Husband Second - Wife First & & & $\begin{array}{c}0.8258 * * * \\
(0.014)\end{array}$ & $\begin{array}{c}0.7873 * * * \\
(0.016)\end{array}$ & $\begin{array}{c}0.8541 * * * \\
(0.017)\end{array}$ \\
\hline Husband_age & & & $\begin{array}{c}1.0357 * * * \\
(0.001)\end{array}$ & $\begin{array}{c}1.0271 * * * \\
(0.001)\end{array}$ & $\begin{array}{c}1.0098 * * * \\
(0.001)\end{array}$ \\
\hline Wife_age & & & $\begin{array}{c}1.0354 * * * \\
(0.001)\end{array}$ & $\begin{array}{c}1.0284 * * * \\
(0.001)\end{array}$ & $\begin{array}{c}1.0091 * * * \\
(0.001)\end{array}$ \\
\hline Wife_education & & & $\begin{array}{c}0.9371 * * * \\
(0.003)\end{array}$ & $\begin{array}{c}0.9539 * * * \\
(0.003)\end{array}$ & $\begin{array}{c}0.9581 * * * \\
(0.004)\end{array}$ \\
\hline Husband_education & & & $\begin{array}{c}1.0748 * * * \\
(0.003)\end{array}$ & $\begin{array}{c}1.0671 * * * \\
(0.003)\end{array}$ & $\begin{array}{c}1.0197 * * * \\
(0.004)\end{array}$ \\
\hline No kids & & & $\begin{array}{c}2.1110 * * * \\
(0.014)\end{array}$ & $\begin{array}{c}2.1979 * * * \\
(0.015)\end{array}$ & $\begin{array}{c}1.7464 * * * \\
(0.012)\end{array}$ \\
\hline Sex of first kid_F & & & $\begin{array}{c}1.7568 * * * \\
(0.008)\end{array}$ & $\begin{array}{c}1.4185 * * * \\
(0.007)\end{array}$ & $\begin{array}{l}0.9961 \\
(0.007)\end{array}$ \\
\hline Husband_une-Wife_emp & & & $\begin{array}{c}1.0392 * * * \\
(0.014)\end{array}$ & $\begin{array}{c}1.0390 * * * \\
(0.015)\end{array}$ & $\begin{array}{c}1.0736 * * * \\
(0.019)\end{array}$ \\
\hline Husband_emp-Wife_une & & & $\begin{array}{c}1.0797 * * * \\
(0.011)\end{array}$ & $\begin{array}{c}1.2272 * * * \\
(0.014)\end{array}$ & $\begin{array}{c}1.0789 * * * \\
(0.016)\end{array}$ \\
\hline Husband_une-Wife_une & & & $\begin{array}{c}0.7680 * * * \\
(0.013)\end{array}$ & $\begin{array}{c}1.2445^{* * *} * \\
(0.023)\end{array}$ & $\begin{array}{c}1.1189 * * * \\
(0.024)\end{array}$ \\
\hline log_Income_Wife & & & $\begin{array}{c}1.1314 * * * \\
(0.005)\end{array}$ & $\begin{array}{c}1.1195 * * * \\
(0.005)\end{array}$ & $\begin{array}{l}1.0110^{*} \\
(0.006)\end{array}$ \\
\hline Log_Income_Husband & & & $\begin{array}{c}1.2920 * * * \\
(0.007)\end{array}$ & $\begin{array}{c}1.1571 * * * \\
(0.007)\end{array}$ & $\begin{array}{c}1.0363 * * * \\
(0.007)\end{array}$ \\
\hline Joint Ownership & & & $\begin{array}{c}0.8834 * * * \\
(0.004)\end{array}$ & $\begin{array}{c}0.8689 * * * \\
(0.004)\end{array}$ & $\begin{array}{c}0.9737 * * * \\
(0.006)\end{array}$ \\
\hline religion & & & $\begin{array}{c}0.8898 * * * \\
(0.005)\end{array}$ & $\begin{array}{c}0.9166 * * * \\
(0.005)\end{array}$ & $\begin{array}{c}0.9017 * * * \\
(0.006)\end{array}$ \\
\hline Log_dist & & & $\begin{array}{c}0.8327 * * * \\
(0.008)\end{array}$ & $\begin{array}{c}0.8338 * * * \\
(0.009)\end{array}$ & $\begin{array}{c}0.9684 * * \\
(0.013)\end{array}$ \\
\hline Husband_asks_separation & & & $\begin{array}{l}0.9908 \\
(0.009)\end{array}$ & $\begin{array}{c}1.0421 * * * \\
(0.010)\end{array}$ & $\begin{array}{c}1.1549 * * * \\
(0.013)\end{array}$ \\
\hline Year control & Yes & Yes & Yes & Yes & Yes \\
\hline Region control & Yes & Yes & Yes & Yes & Yes \\
\hline Observations & 251,080 & 251,080 & 251,080 & 218,237 & 129,355 \\
\hline Wald Statistic & 4397 & 4569 & 66273 & 89375 & 15851 \\
\hline
\end{tabular}

Separations ISTAT datasets (2008-2010), Italy. Hazard rates reported . The reference omitted group is of Homogamous Italian couples at first marriage. Inter-ethnic refers to families where one spouse is native and the other one was born abroad. Region and year of marriage fixed effects are included in all specifications. Columns (4-5) report estimates for specific marriage year categories. Robust standard errors in parentheses. Significance level: *** $\mathrm{p}<0.01, * * \mathrm{p}<0.05, * \mathrm{p}<0.1$. 
The other coefficients of column 3 confirm many of the findings of the literature. Controlling for time and regional effects, we find that couples with no children have an instantaneous probability of a break-up that is double than that of couples with at least one kid. ${ }^{6}$ Moreover, the hazard rate is higher for spouses at their first marriage relative to those who remarried. The effect is stronger when the husband is at his first marriage and the wife is at her second. Couples who marry at a younger age show a higher hazard rate of separation, and this is true for both spouses (see the significant coefficient of both the wife's age at marriage and of the age difference between husband's and wife's ages). We find an interesting asymmetric effect of education on the separation rate. More educated wives tend to separate earlier, while more educated husbands later. This may be due to the fact that more educated women are economically more "independent" from men or are more confident in finding a better match, although this effect holds even when, as we do, we control for spouses' incomes.

Indeed, the estimated coefficients of spouses' incomes are above one, which says that higher income spouses have a higher break-up probability. A separation is a costly endeavour, as it often implies a doubling of expenditures, such as house rents, for a given family income. Thus, "freedom" from an unhappy relationship is a "normal" good.

The labour market characteristics are also quite interesting: when either spouse is unemployed, while the other is employed, the hazard rate of separation is significantly above one, implying a shorter marriage. This finding is consistent with the results coming from the sociological literature on the impact of unemployment on divorce rates (Killewalda, 2016; Lester, 1996). However, when both spouses are unemployed the marriage survival rate increases sharply (the hazard falls to 0.77) implying a longer-than-average duration of about 4.5 years. One possible interpretation is that spouses act egoistically: the employed spouse who is also the economically stronger party (particularly if he is the husband) may decide to leave the unemployed partner, who has become a psychological and economic burden. However, when both spouses are unemployed, no one has an incentive to leave the other, given the high costs of a separation.

Column 3 in Table 2 introduces other covariates which are not directly related to the spouses' economic situation or education. Couples whose first-born is female show a significantly higher separation rate compared to other couples. This confirms the result obtained by Dahl and Moretti (2008), who found evidence of a gender bias against girls in the parents' decision to separate.

\footnotetext{
${ }^{6}$ We omit from the regression variable "number of children" of the couple at the separation date. This variable is significantly negatively associated to the separation rate, although reverse causality (i.e., more stable couples have more children) cannot be easily ruled out.
} 
We also account for geographical distance which is usually considered a measure of cultural distance. We calculate the (log) distance between places of birth of Italian spouses from the Geo data base. As explained earlier, we are interested in exploring whether the "North-South" cultural divide (stereotyped by an efficient/work-oriented North vs a familial/corrupt South) plays any role in marriage resilience. For inter-ethnic couples, we calculate the distance between countries' capitals (Rome for Italian inter-ethnic marriages). Surprisingly, we find that a greater distance between birth places is associated to longer-lasting marriages, implying a sort of negative assortative mating. Rather than pointing to a North-South cultural divide, this finding is consistent with idea that spouses may specialize in their respective comparative advantages (e.g., the northerner in "bread-winning" and the southerner in home-cooking, for a stereotyped example), raising the value of the match and delaying separation.

We also use a dummy variable for the choice of religious versus non-religious wedding rite, and one for the choice of a common versus separation property regime, our measures of commitment to the marriage discussed earlier. As expected, the coefficient of the religious rite dummy ("Religion") is significantly below one, implying that religious marriages last about two years longer than civil marriages. The "joint property regime" variable is also significantly associated to a lower separation hazard rate, or to a longer lasting marriage, confirming our interpretation.

Finally, we test if the identity of the spouse asking for the separation is informative about the marriage survival rate. We employ the dummy variable "separation request" which takes the value of 1 if the process of separation is initiated by the husband, and zero otherwise (either joint or wife request). The estimated coefficient of this variable is not statistically significantly different from one, indicating that the identity of the "first-mover" is not relevant for marriage duration.

\subsubsection{Cohort Effects}

We saw earlier that inter-ethnic marriages were very rare until recently. Moral values and civil attitudes towards the family, marriage, and divorce have dramatically changed in Italy since divorce was legalized in the late seventies. Indeed, the fraction of marriages ending in divorce has almost doubled, from 2\% in 1980 to $9 \%$ in 2014 (Eurostat, 2016). Since then, single-parent families have become more common and the social stigma associated to separations have disappeared. Even the Church is now revising her policy of excluding divorcees from Sacraments. Our sample records Italian co-ethnic marriages dating back up to 65 years, while inter-ethnic marriages only go back 12 years at most. As a result, the shorter duration of inter-ethnic marriages may simply reflect the fact that they were celebrated much more recently (cohort effect), at a time when separations had 
become much more common, for all marriages. To test this hypothesis, we perform all the previous estimations by restricting the sample to marriages celebrated since 1980 (about 218,237 observations compared to the initial 251,080, fourth column of the Table 2), and further to marriages celebrated since 1994 (129,355 observations, see the last column of the table). We consider these cohorts of marriages so that there are at least 15 years (the average marriage duration) between the different cohorts. Looking in particular to the results for the most recent marriages, the size of the estimated effect of an inter-ethnic marriage falls considerably, while retaining its statistical significance. It now implies that an inter-ethnic marriage is 1.2 years shorter than a co-ethnic one. Note, however, that by construction, the duration of the most recent marriages falls moving to more recent cohorts, since we only consider separations that occur in the period 2008-2010. What is important, however, is that the relative effect of inter-ethnic marriages falls considerably, as reflected in the estimated coefficient of the variable "mixed". Considering the sample all marriages, the longevity of an inter-ethnic marriage is 43 percent $(=6.5 / 15)$ shorter than the average, while this effect falls to about 16 percent $(=1.2 / 7.5)$ when considering only marriages celebrated since 1994. Most of the other coefficients in the regressions estimated for the more recent marriages are very similar to the ones estimated for the entire sample, with the exception of the asymmetric effect of the unemployment status, which disappears, and of the husband separation-request, which, on the contrary, becomes significant ad positively associated to the hazard rate.

Interestingly, the effect of a first-born daughter becomes insignificant, suggesting a shift away from female discrimination. The main result we draw from this section is that the longevity of inter-ethnic and co-ethnic marriages appears to be converging when we consider more recent marriages.

\subsection{Survival Treatment Effects Estimation}

This section addresses the "causal" relationship between marrying "over the moor" (i.e., a foreigner) and the associated marriage duration. The first issue is the "missing counterfactual" that we have discussed earlier: what if native spouses in inter-ethnic partnerships had married co-natives (and vice-versa)? To address this question, we estimate a "treatment-effect" model of duration, where "mixed marriage" is the "treatment." We employ different techniques in order to obtain robust results. The first is the "regression adjustment" approach (Wooldridge, 2010).

This methodology fits one model of duration separately for the "treated" (inter-ethnic couples) and one for "non-treated" (co-ethnic), using the same covariates employed in the Cox regressions. Predicted durations are used for estimating the marriages' "potential duration". The 
average "treatment effect" (ATE) of "inter-ethnic marriage" is the average difference in the time to separation that would occur if all couples were inter-ethnic (obtained by predicting durations using the estimates of the inter-ethnic model) relative to that which would occur if they were all co-ethnic (obtained by predicting durations using the estimates of the co-ethnic model). The results are shown in Table 3. The ATE in the first column refers to the entire sample. Here an inter-ethnic marriage reduces the time-to-separation by about 2.2 years, relative to an average duration of more than 15 years for co-ethnic marriages (15\% reduction). The coefficient is highly statistically significant, and the effect is much smaller than that obtained in the corresponding hazard rate regressions $(6.5$ years). Table 3 also reports the ATE for the restricted sample of separations of marriages celebrated since 1980, and since 1994. The size of the estimated effect of inter-ethnic marriages is reduced to about 1.6 years, and is not statistically different from zero in the sample of the most recent marriages. Again, we find evidence of a convergence in duration over time.

Table 3: Average treatment Effect of Inter-Ethnic Marriages

\begin{tabular}{cccc}
\hline ATE & $1947-2010$ & $1980-2010$ & $1994-2010$ \\
\hline $\begin{array}{c}\text { Mixed } \\
(1 \text { vs } 0)\end{array}$ & $-2.2094^{* *}$ & $-1.6636^{* * *}$ & $-0.6371^{* * *}$ \\
POmean & $(0.2795)$ & $(-0.2150)$ & $(0.1198)$ \\
Mixed & & $12.2462^{* * *}$ & \\
0 & $15.3254 * * *$ & $(0.0188)$ & $(0 . .0139)$ \\
& $(0.0241)$ & 218,302 & 129,419 \\
\hline Number of obs & 251,145 & & \\
\hline *The results do not consider time and regions fixed effects &
\end{tabular}

*The results do not consider time and regions fixed effects

\subsection{Endogenous Treatment Effects}

In order to interpret the inter-ethnic marriage as a "cause" of early break-up, the potential outcomes (the duration of a marriage) should be independent of "treatment" assignment (the decision of spouses to marry a partner born in a different country). In our case, however, the treatment is not necessarily a random event, and may depend on unobserved characteristics of the spouse that also affect the marriage duration. Consider the following examples. Suppose that spouses who have a "liberal/secular attitude" are more open to cultural diversity and are more likely to choose an inter-ethnic marriage. Because of their attitudes, they may be less attached to the idea of "un-dissolvability" of marriage, and are more prone to separation. If we do not control for these characteristics, we may attribute the shorter duration of the marriage to its "inter-ethnic" nature, and overestimate its negative effect on duration. In other words, it may be that more "secular" people 
are keener about marrying a foreigner and are culturally less averse to a divorce, rather than that inter-ethnic couples experience harsher conflicts and therefore split sooner. The bias could go either way, however. Consider a native spouse who is less "marketable" on the Italian marriage market due to some unmeasured trait (e.g., has a health problem). Alternatively, the foreign spouse may be in "excess genre-supply," as for example, a female from Eastern Europe or a male from Africa. ${ }^{7}$ As a result, both spouses may be more averse to separation because they are less likely to find another partner. If we neglect the fact that the same characteristics that induce spouses to self-select into inter-ethnic marriages also make them hold on longer to each other, we may in this case underestimate the negative impact of inter-ethnic marriages on its duration. Summarizing the discussion, for interpreting our "inter-ethnic" marriage dummy effect as a "cause" of early separation, we would require "conditional independence": the assignment of individuals to the treatment (the inter-ethnic marriage) conditional on covariates, should be "as good as random." 8

\subsubsection{Linear Model with Endogenous Treatment}

We address this issue by implementing a linear model with endogenous treatment (Heckman, 1976, 1978). This approach estimates two separate models: one for the outcome, timeto-separation for the couple $j, t_{j}$ in equation (1), and one for the treatment assignment, Mix $x_{j}$ in equation (2) below. The marriage duration depends on covariates $x_{j}$ 's, while the assignment of couple $j$ to an inter-ethnic marriage depends on covariates $w_{j}$, which may include the $x_{j}$ 's. The idea is to account for the possibility that some of the couple's unobserved characteristics that affect marriage longevity, and captured by $\varepsilon_{j}$, may be correlated to those which influence the choice of an inter-ethnic marriage, $u_{j}$, where $u_{j}$ and $\varepsilon_{j}$ are error terms that are assumed to be normal, with zero mean and covariance matrix $\Sigma$, and are assumed to be independent of the covariates $x, w$.

$$
\begin{aligned}
& \text { (1) } t_{j}=x_{j} \beta+\gamma M i x_{j}+\varepsilon_{j} \\
& \text { (2) } M i x_{j}= \begin{cases}1 \text { if } w_{j} \delta+u_{j}>0 \\
0, & \text { otherwise }\end{cases} \\
& \text { (3) } \Sigma=\left[\begin{array}{cc}
\sigma^{2} & \rho \sigma \\
\rho \sigma & 1
\end{array}\right]
\end{aligned}
$$

The important parameter in the above model is $\rho$, the coefficient of correlation between the disturbances of the two equations. If this parameter is negative and statistically significant, for example, the unobserved characteristics that are associated to shorter marriage durations are also associated to higher propensities to marry inter-ethnically, as in the "liberal/secular attitude"

\footnotetext{
${ }^{7}$ In order to account for this, we would need information on the genre balances for all countries of origin, at the time of the marriage and in each region of residence, which is not available.

${ }^{8}$ Wooldridge (2010)
} 
example discussed previously. In this case, accounting for this effect should result in a smaller estimated negative impact of the inter-ethnic marriage on duration (a higher absolute value for $\gamma$ $<0$ ), relatively to the previous estimates. If the estimate of $\rho$ is positive and significant, the opposite is true as in the "physically ill/excess supply" examples, where couples who self-select into interethnic partnerships have marriages that are more likely to last longer. In this case, correcting for this correlation should produce a larger (negative) estimated impact of inter-ethnic marriage on duration.

The duration equations are reported in columns 1, 3, and 5 of Table 4, for the different cohorts according to the years of marriage formation. The regressions contain the same covariates as the previous models. In the self-selection equation (2) reported in columns 2, 4, and 6 for the different cohorts, we have included variables that may affect both the choice of an inter-ethnic marriage and its duration, such as the spouses' age at marriage and the first marriage dummy variable, as well one new variable, "same religion not Italian." This variable is constructed from the Pew Research Centre data for the religion diffusion in different countries in 2010, and captures the fact the foreign spouse in the Italian inter-ethnic marriages are born in predominantly Christian countries. The idea is to capture a preference for marrying those foreigners who share the same (or a similar) religion.

The results are reported in Table 4. All covariates in the duration equations (columns 1, 3, and 5) appear significant and, in general, with the same sign as in previous regression estimations, although the size of the coefficients generally decrease as the sample sizes shrink. In particular, the negative effect of an inter-ethnic marriage on the marriage duration falls from 5.1 to 3.2 years, when we restrict the analysis from the entire sample (column 1) to that of marriages celebrated from 1980 (column 3), partially reflecting the widespread reduction in all marriages' life. In the most recent sample (column 5), the coefficient becomes negative, which literally implies that inter-ethnic marriages last about 2 months longer than co-ethnic ones. As before, a religious rite and the choice of a common property regime are associated to a longer-lasting marriage. There are a few differences with respect to the previous estimations using Cox regressions. The first is the effect of the unemployed spouse, which was earlier shown to be associated with shorter marriage duration. Instead here, the unemployed husband/employed wife dummy variable is positively associated to duration. When we restrict the sample to more recent marriages the previous negative effect shows up. Another difference is the "balance-of-power" indicator, the husband's application for separation, which becomes significant in the two more recent samples. Finally, here a marriage last longer when either spouse has remarried. 
Table 4. Linear Model with Self-Selection into Inter-Ethnic Marriage

\begin{tabular}{|c|c|c|c|c|c|c|}
\hline VARIABLES & $\begin{array}{c}\text { Duration } \\
1947-2010 \\
(1) \\
\end{array}$ & $\begin{array}{c}\text { Inter-ethnic } \\
1947-2010 \\
(2)\end{array}$ & $\begin{array}{c}\text { Duration } \\
1980-2010 \\
(3) \\
\end{array}$ & $\begin{array}{c}\text { Inter-ethnic } \\
1980-2010 \\
(4)\end{array}$ & $\begin{array}{c}\text { Duration } \\
1994-2010 \\
(5) \\
\end{array}$ & $\begin{array}{c}\text { Inter-ethnic } \\
1994-2010 \\
(6) \\
\end{array}$ \\
\hline Inter-ethnic & $\begin{array}{c}-5.1472 * * * \\
(0.151)\end{array}$ & & $\begin{array}{c}-3.1878 * * * \\
(0.121)\end{array}$ & & $\begin{array}{c}-0.2291 * * * \\
(0.087)\end{array}$ & \\
\hline Husband Second-Wife Second & $\begin{array}{c}3.0236 * * * \\
(0.143)\end{array}$ & $\begin{array}{l}0.0093 \\
(0.042)\end{array}$ & $\begin{array}{c}2.8776 * * * \\
(0.117)\end{array}$ & $\begin{array}{l}0.0165 \\
(0.042)\end{array}$ & $\begin{array}{c}0.9406 * * * \\
(0.084)\end{array}$ & $\begin{array}{l}0.0295 \\
(0.046)\end{array}$ \\
\hline Husband First - Wife Second & $\begin{array}{c}1.4052 * * * \\
(0.111)\end{array}$ & $\begin{array}{c}0.3470 * * * \\
(0.034)\end{array}$ & $\begin{array}{c}1.1490 * * * \\
(0.093)\end{array}$ & $\begin{array}{c}0.3551 * * * \\
(0.034)\end{array}$ & $\begin{array}{c}0.3514 * * * \\
(0.063)\end{array}$ & $\begin{array}{c}0.3507 * * * \\
(0.038)\end{array}$ \\
\hline Husband Second - Wife First & $\begin{array}{c}1.7739 * * * \\
(0.104)\end{array}$ & $\begin{array}{c}0.1022 * * * \\
(0.031)\end{array}$ & $\begin{array}{c}1.5347 * * * \\
(0.091)\end{array}$ & $\begin{array}{c}0.1012 * * * \\
(0.031)\end{array}$ & $\begin{array}{c}0.5768 * * * \\
(0.064)\end{array}$ & $\begin{array}{c}0.1149 * * * \\
(0.035)\end{array}$ \\
\hline Husband_age & $\begin{array}{c}-0.2226 * * * \\
(0.003)\end{array}$ & $\begin{array}{c}0.0245 * * * \\
(0.001)\end{array}$ & $\begin{array}{c}-0.1394 * * * \\
(0.003)\end{array}$ & $\begin{array}{c}0.0238 * * * \\
(0.001)\end{array}$ & $\begin{array}{c}-0.0347 * * * \\
(0.002)\end{array}$ & $\begin{array}{c}0.0234 * * * \\
(0.001)\end{array}$ \\
\hline Wife_age & $\begin{array}{c}-0.2715 * * * \\
(0.004)\end{array}$ & $\begin{array}{c}-0.0068 * * * \\
(0.001)\end{array}$ & $\begin{array}{c}-0.1830 * * * \\
(0.003)\end{array}$ & $\begin{array}{c}-0.0091 * * * \\
(0.001)\end{array}$ & $\begin{array}{c}-0.0362 * * * \\
(0.002)\end{array}$ & $\begin{array}{c}-0.0136^{* * * *} \\
(0.001)\end{array}$ \\
\hline Wife_education & $\begin{array}{c}0.6214 * * * \\
(0.020)\end{array}$ & & $\begin{array}{c}0.3357 * * * \\
(0.016)\end{array}$ & & $\begin{array}{c}0.1337 * * * \\
(0.012)\end{array}$ & \\
\hline Husband_education & $\begin{array}{c}-0.5448 * * * \\
(0.020)\end{array}$ & & $\begin{array}{c}-0.3744 * * * \\
(0.016)\end{array}$ & & $\begin{array}{c}-0.0631^{* * * *} \\
(0.012)\end{array}$ & \\
\hline No kids & $\begin{array}{c}-1.8833 * * * \\
(0.102)\end{array}$ & & $\begin{array}{c}-0.6790 * * * \\
(0.080)\end{array}$ & & $\begin{array}{c}-0.3540 * * * \\
(0.057)\end{array}$ & \\
\hline Sex of first kid_F & $\begin{array}{c}-1.2929 * * * \\
(0.076)\end{array}$ & & $\begin{array}{c}-1.3327 * * * \\
(0.061)\end{array}$ & & $\begin{array}{c}-0.3051^{* * * *} \\
(0.046)\end{array}$ & \\
\hline Husband_une-Wife_emp & $\begin{array}{c}0.6503 * * * \\
(0.126)\end{array}$ & & $\begin{array}{c}-2.1256 * * * \\
(0.094)\end{array}$ & & $\begin{array}{c}-0.5846 * * * \\
(0.068)\end{array}$ & \\
\hline Husband_emp-Wife_une & $\begin{array}{c}-0.9433 * * * \\
(0.032)\end{array}$ & & $\begin{array}{c}-0.5845 * * * \\
(0.026)\end{array}$ & & $\begin{array}{r}-0.0092 \\
(0.019)\end{array}$ & \\
\hline Husband_une-Wife_une & $\begin{array}{c}-2.9075 * * * \\
(0.041)\end{array}$ & & $\begin{array}{c}-0.9098 * * * \\
(0.031)\end{array}$ & & $\begin{array}{c}-0.1074 * * * \\
(0.023)\end{array}$ & \\
\hline log_Income_Wife & $\begin{array}{c}-6.9289 * * * \\
(0.043)\end{array}$ & & $\begin{array}{c}-5.4059 * * * \\
(0.033)\end{array}$ & & $\begin{array}{c}-2.3992 * * * \\
(0.023)\end{array}$ & \\
\hline Log_Income_Husband & $\begin{array}{c}-4.9825 * * * \\
(0.037)\end{array}$ & & $\begin{array}{c}-1.9819 * * * \\
(0.032)\end{array}$ & & $\begin{array}{l}0.0311 \\
(0.026)\end{array}$ & \\
\hline Joint Ownership & $\begin{array}{c}1.0601 * * * \\
(0.034)\end{array}$ & & $\begin{array}{c}0.9174 * * * \\
(0.027)\end{array}$ & & $\begin{array}{c}0.1362 * * * \\
(0.020)\end{array}$ & \\
\hline Religious rite & $\begin{array}{c}1.4590 * * * \\
(0.039)\end{array}$ & & $\begin{array}{c}0.8954 * * * \\
(0.031)\end{array}$ & & $\begin{array}{c}0.4819 * * * \\
(0.022)\end{array}$ & \\
\hline Log_dist & $\begin{array}{c}1.7872 * * * \\
(0.072)\end{array}$ & & $\begin{array}{c}1.1358 * * * \\
(0.059)\end{array}$ & & $\begin{array}{c}0.0888 * * \\
(0.043)\end{array}$ & \\
\hline Husband_asks_separation & $\begin{array}{r}-0.1011 \\
(0.063)\end{array}$ & & $\begin{array}{c}-0.2459 * * * \\
(0.049)\end{array}$ & & $\begin{array}{c}-0.4845 * * * \\
(0.036)\end{array}$ & \\
\hline Year control & Yes & & Yes & & Yes & \\
\hline Region control & Yes & Yes & Yes & Yes & Yes & Yes \\
\hline same_rel_no_Ita & & $\begin{array}{c}3.1490 * * * \\
(0.020)\end{array}$ & & $\begin{array}{c}3.1176 * * * \\
(0.021)\end{array}$ & & $\begin{array}{c}3.0702 * * * \\
(0.025)\end{array}$ \\
\hline rho & $\begin{array}{c}0.0389 * * * \\
(0.0073)\end{array}$ & & $\begin{array}{c}0.0259 * * * \\
(.0074)\end{array}$ & & $\begin{array}{c}-0.0264 * * * \\
(.0088)\end{array}$ & \\
\hline Observations & 251,080 & & 218,237 & & 129,355 & \\
\hline Wald Statistic & 153843 & & 89375.50 & & 25208.57 & \\
\hline Prob > chi 2 & 0.0005 & & 0.0005 & & 0.0028 & \\
\hline
\end{tabular}


Particularly interesting are the equations for the treatment assignment shown in columns 2, 4, and 6. Spouses at their second (or later) marriages, mostly husbands, are more likely to self-select into inter-ethnic marriages. The husband's age at marriage, unlike the wife's, also comes out with a positive sign in all duration regressions, implying that older men and younger women are more likely to choose inter-ethnic marriages. A positive coefficient for the variable "same-religion-noItalian" indicates that an inter-ethnic marriage is more likely to occur when the foreign spouse is Catholic. This variable is strongly significant across all samples considered. This assortative mating for religious proximity is a plausible explanation for the relative scarcity of marriages of Italian women with foreign (non-Catholic) men, mostly from North Africa, and the relative abundance of marriages of Italian men with Eastern European women.

One interesting feature of this model is the correlation coefficient $\rho$, which turns out significant and positive using the full sample, supporting the conjecture that unobservable features of the "ill" or "excess-supply" type induce self-selection into inter-ethnic marriages and are at the same time associated with longer marriages. However, when we move to the sample of marriages formed in 1994-2010 (column 6), the correlation coefficient $\rho$ becomes negative, indicating the prevalence of the "secular/liberal attitude" bias that induces inter-ethnic marriages as well as early separation. This result is consistent with the very small (and positive) effect that inter-ethnic marriages exert on duration for this sub-sample: we observe a full convergence in duration between co-ethnic and inter-ethnic marriages, which confirms the view that the Italian society is becoming more secular, with increased occurrence of inter-ethnic marriages and shorter marriages.

\section{Conclusions.}

This paper has exploited a novel dataset containing information on all the separations that took place in Italy in the years 2008-10 in order to assess the relative longevity of marriages involving spouses born in different countries. We measure marriage stability by its duration or longevity. On the average, an inter-ethnic marriage lasts about one-third less than a marriage between co-natives. Our main findings are as follows. First, even when we control for social and economic characteristics of the spouses, we find that an inter-ethnic marriage entails a significantly higher risk of separation. Second, separations tend to occur when spouses marry at younger ages, when either (but not both) is unemployed, when there are no kids, when the first kid is female, when spouses celebrate a religious wedding rite and choose a common property regime, when the wife/husband is more/less educated, and when spouses earn a higher income. Third, when we restrict the analysis to more recent marriages, we observe that co-ethnic and inter-ethnic marriages converge in longevity. Finally, we find evidence of self-selection into inter-ethnic marriages: 
spouses which are either "less marketable" in the co-ethnic marriage market, or are "in excess supply" tend to self-select into inter-ethnic marriages. Also, spouses self-select into inter-ethnic couples more frequently when they share the same religion. In the most recent cohorts of marriages, we observe a different kind of self-selection: that of "less secular type" of spouses, who are more open to ethnic diversity and less attached to the marriage. Taken together with the estimated convergence in marriage longevity, this finding points to a society that is becoming open to cultural and ethnic diversity and more secular, and where integration of the recent waves of immigrants seems to proceed together with the acceptance of diversity. 


\section{References}

Aassve, A., Betti, G., Mazzuco, S., and Mencarini, L. (2007). Marital Disruption and Economic Well-being: A Comparative Analysis. Journal of the Royal Statistical Society: Series A (Statistics in Society), 170(3): 781-799.

Algan,Y.,Bisin,A.,Manning,A. and Thierry Verdier (2012). Cultural integration of immigrants in Europe, Oxford Universty Press,

Bank of Italy, Survey on Household Income and Wealth (SHIW), https://www.bancaditalia.it/statistiche/tematiche/indagini-famiglie-imprese/bilanci-famiglie/

Becker, G. (1974). A Theory of Marriage. Journal of Political Economy, 81(4): 813-846.

Becker, G. S., Landes, E. M., and Michael, R. T. (1977). An Economic Analysis of Marital Instability. Journal of Political Economy, 85(6): 1141-1187.

Bisin, A. and Verdier, T. (2010). The Economics of Cultural Transmission and Socialization. NBER Working Paper No. 16512.

Bratter, J. L. and King, R. B. (2008). "But Will It Last?”: Marital Instability Among Interracial and Same-Race Couples. Family Relations, 57(2): 160-171.

Chiappori, P., Oreffice, S., and Quintana-Domeque, C. (2012). Fatter Attraction: Anthropometric and Socioeconomic Matching on the Marriage Market. Journal of Political Economy, 120(4): 659-695.

Choo, E. (2015). Dynamic Marriage Market: An Empirical Framework. Econometrica, 83(4): $1373-1423$.

Choo, E. and Siow, A. (2006). Who Marries Whom and Why. Journal of Political Economy, 114(1): 175-201.

Constant, A. and Zimmerman, K. (2008). Measuring ethnic identity and its impact on economic behavior, Journal of the European Economic Association 6 (2- 3), 424-433

Constant, A.,Kahanec,M.,and KF Zimmermann et (2009), Attitudes towards immigrants, other integration barriers, and their veracity, International Journal of Manpower

Cox, D. (1972). Regression Models and Life-Tables. Journal of the Royal Statistical Society, Series B, 34(2): 187-220.

Dahl, G., and Moretti, E. (2008). The Demand for Sons. The Review of Economic Studies 75: $1085-1120$.

De Rose, A. (1992). Socio-Economic Factors and Family Size as Determinants of Marital Dissolution in Italy. European Sociological Review, 8(1): 71-91. 
Dribe, M. and Lundh, C. (2011). Cultural Dissimilarity and Intermarriage. A Longitudinal Study of Immigrants in Sweden 1990-2005. International Migration Review, 45(2): 297-324.

Dupuy,A. and Alfred Galichon. (2014).Personality traits and the marriage market (2014). With Arnaud Dupuy. Journal of Political Economy 122 (6), pp. 1271-1319.

Eurostat, (2016). Marriage and Divorce Statistics, http://ec.europa.eu/eurostat/statisticsexplained/index.php/Marriage_and_divorce_statistics

Feng, Z., Boyle, P., Ham, M., and Raab, G. (2012). Are Inter-Ethnic Unions More Likely to Dissolve Than Co-Ethnic Unions? New Evidence from Britain. European Journal of Population, 28(2): 159-176.

Frimmel, W., Halla, M., and Winter-Ebmer, R. (2012). Assortative mating and divorce: evidence from Austrian register data. Journal of the Royal Statistical Society: Series A (Statistics in Society), 176:1-23.

Furtado, D., Marcen, M., and Sevilla-Sanz, A. (2013). Does Culture Affect Divorce Decisions? Evidence from European Immigrants in the US. Demography, 50(3): 1013-1038.

GeoDataSource, http://www.geodatasource.com/developers/php

Gruber, J. (2004). Is Making Divorce Easier Bad for Children? The Long-Run Implications of Unilateral Divorce. Journal of Labor Economics, 22(4): 799-833.

Heaton, T. B. (2002). Factors Contributing to Increasing Marital Stability in the United States. Journal of Family Issues, 23(3): 392-409.

Heckman, J. (1976). The Common Structure of Statistical Models of Truncation, Sample Selection and Limited Dependent Variables and A Simple Estimator for Such Models. Annals of Economic and Social Measurement 5: 475-492.

Heckman, J. (1978). Dummy Endogenous Variables in A Simultaneous Equation System. Econometrica 46: 931-959.

Humbad, M. N., Donnellan, M. B., Iacono, W. G., McGue, M., and Burt, S. A. (2010). Is Spousal Similarity for Personality a Matter of Convergence or Selection? Personality and Individual Differences, 49(7): 827-830.

ISTAT. (2014), Matrimoni, Separazioni e Divorzi, www.istat.it/it/files/2015/11/Matrimoniseparazioni-e-divorzi-2014.pdf

Jones, A. (2010). Stability of Men's Interracial First Unions: A Test of Educational Diff erentials and Cohabitation History. Journal of Family and Economic Issues, 31: 241-256.

Kalmijn, M., de Graaf, P. M., and Janssen, J. P. (2005). Intermarriage and the Risk of Divorce in the Netherlands: The Effects of Differences in Religion and in Nationality, 1974-94. Population Studies, 59(1): 71-85. 
Killewalda, A. (2016). Work, and Marital Stability: Assessing Change in the Gendered Determinants of Divorce. American Sociological Review, July

Lehrer, E. L. (2008). Age at Marriage and Marital Instability: Revisiting the Becker- LanderMichael Hypothesis. Journal of Population Economics, 21: 463-484.

Lester D. (1996). The Impact of Unemployment on Marriage and Divorce. Journal of Divorce and Remarriage, 25(3-4): 151-153.

Manasse, P. and See, S. G. (2013). Marital Dissolution in Italy. Are Inter-Ethnic Couples More Likely to Separate? (mimeo, University of Bologna), paper presented at the DSE Economics Seminar.

Meng, X. and Gregory, R. (2005). Intermarriage and the Economic Assimilation of Immigrants. Journal of Labor Economics, 23(1): 135-174.

Milewski, N. and H. Kulu, (2014) Mixed Marriages in Germany: A High Risk of Divorce for Immigrant-Native Couples European Journal of Population 30:

Monahan, T. P. (1970). Are Interracial Marriages Really Less Stable? Social Forces, 48(4): 461473.

Pew Research Center, www.pewresearch.org/data/

Salvini, S. and Vignoli, D. (2011). Things Change: Women's and Men's Marital Disruption Dynamics in Italy During A Time of Social Transformations, 1970-2003. Demographic Research, 24: 145-174.

Stata (2015). Introduction to treatment effects in Stata, http://blog.stata.com/2015/07/07/introduction-to-treatment-effects-in-stata-part-1/

Stevenson, B. and Wolfers, J. (2007). Marriage and Divorce: Changes and Their Driving Forces. Journal of Economic Perspectives, 21(2): 27-52.

Teachman, J. (2002). Stability Across Cohorts in Divorce Risk Factors. Demography, 39(2): 331351.

The Bible. (1998). Authorized King James Version. Oxford University Press.

Tolsma, J., Lubbers, M., and Coenders, M. (2008). Ethnic Competition and Opposition to Ethnic Intermarriage in the Netherlands: A Multi-Level Approach. European Sociological Review 24(2): 215-230.

Van Ham, H. and Tammaru, M. (2011). Ethnic Minority-Majority Unions in Estonia. European Journal of Population, 27(3): 313-335.

van Huis, M. and Steenhof, L. (2003). Divorce Risk for Foreigners in the Netherlands. Paper for Euresco conference "The Second Demographic Transition in Europe”, June 19-24, 2003, Belgium. 
Vignoli, D. and Ferro, I. (2009). Rising Marital Disruption in Italy and Its Correlates. Demographic Research, 20: 11-36.

Wooldridge. (2010). Econometric Analysis of Cross Section and Panel Data. MIT Press

Zhang, Y. and Van Hook, J. (2009). Marital Dissolution Among Interracial Couples. Journal of Marriage and Family, 71(1): 95-107. 


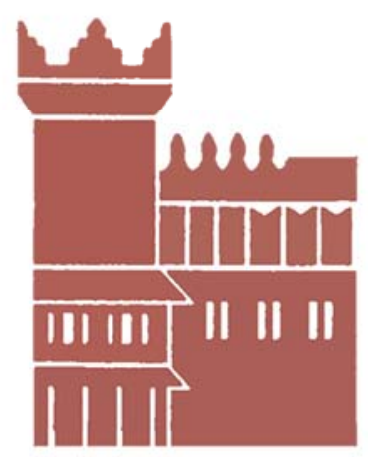

Alma Mater Studiorum - Università di Bologna DEPARTMENT OF ECONOMICS

Strada Maggiore 45

40125 Bologna - Italy

Tel. +39051 2092604

Fax +390512092664

http://www.dse.unibo.it 